\title{
THE INFLUENCE OF PROFESSIONAL COMPETENCIES ON THE ECONOMIC CONDITION OF THE ORGANIZATIONS IN THE MECHANICAL ENGINEERING SECTOR IN BULGARIA
}

\author{
Milena Tepavicharova ${ }^{1}$, Ludmila Aleksejeva $^{2}$ \\ ${ }^{1}$ Higher School of Security and Economics - Plovdiv, Bulgaria \\ ${ }^{2}$ Daugavpils university, Daugavpils, Latvia \\ e-mails: ${ }^{1} \underline{m}$ ivanova_zlatanova@abv.bg, ${ }^{2}$ ludmila.aleksejeva@du.lv
}

Received: 01 March 2020; Accepted: 28 April 2020; Published: 09 June 2020

\begin{abstract}
The technological changes, under the influence of scientific and technological progress and trends in the mechanical engineering, inevitably lead to modifications in the characteristics of the existing jobs and the creation of new such with other characteristics. Therefore, regardless of the depth and speed of the changes in the technological facilities for production, ever more important for the efficiency in most machine-building enterprises will be the qualities and skills of the workforce in the coming years. Modifications in the parameters and organization of the workplaces will change the content of the tasks and as a consequence, will alter the vocational qualification requirements for the employed. In this sense, the development of the professional competencies is an important internal reserve for the economic growth of the organization. The purpose of this article is to analyze the status and development of the professional competencies of the labor force in the mechanical engineering sector, and to evaluate their role in improving the economic situation in the business organizations in Bulgaria.
\end{abstract}

Key words: professional competencies, mechanical engineering, economic condition, technological and economical trends, innovation and economic opportunities, development, innovations economics.

JEL classification: L10; O31; O39; O40

\section{How to Cite:}

Tepavicharova, M., Aleksejeva, L. (2020). The influence of professional competencies on the economic condition of the organizations in the mechanical engineering sector in Bulgaria. Access journal, ACCESS Press, 1(1): 61-71.

DOI: $\underline{\text { https://doi.org/10.46656/access.2020.1.1(5) }}$

\section{INTRODUCTION}

The membership The provision of the mechanical engineering in the country with the required quantity and quality of labor force is influenced by a number of external and internal risk factors - arising of new global financial and economic crises, negative alterations in the economic and institutional environment, factors related to changes in the the labor and management of the company, etc. The deepening shortage of highly skilled personnel is becoming a vivid risk problem for the mechanical sector. At some stage, the functional capacity (quality) of the workforce may not be sufficient to meet the ever growing demands of the new technologies, of the partners in the cooperative industries and of the markets. 
The technological changes, under the influence of scientific and technological progress and trends in the mechanical engineering, inevitably lead to modifications in the characteristics of the existing jobs and the creation of new such with other characteristics. Therefore, regardless of the depth and speed of the changes in the technological facilities for production, ever more important for the efficiency in most machine-building enterprises will be the qualities and skills of the workforce in the coming years. Modifications in the parameters and organization of the workplaces will change the content of the tasks and as a consequence, will alter the vocational qualification requirements for the employed (Nikolova-Alexieva, Teneva \& Yordanova, 2018; Sushchenko, 2016). In this sense, the development of the professional competencies is an important internal reserve for the economic growth of the organization.

Along with cost optimization, company innovativeness (Pukala \& Petrova, 2019), depending on the adopted development strategy, each enterprise may use different policies and specific actions to meet the needs for staff with the required skills and competencies. In the context of financial constraints, it is important to focus on the internal reserves in the organization of all the workforce processes - forecasting the needs and expected changes in the required skills and competencies, optimizing budgets, selecting, evaluating, work pay and stimulus, vocational training and advanced training (Mikhailov, Karasev \& Mikhailov, 2018; Levashova, 2011 ; Mussaripov et al, 2019; Zagorodnya et al, 2020).

Building a set of professional competencies of the workforce requires focused actions to improve certain knowledge, skills and abilities. (Uteubayev, Petrova \& Lyubenova, 2018; Koval et al, 2019; Naama, 2010; Naama, 2018, Vazov, 2019). Their development has a direct or indirect impact on the results of the production and economic activity in the economic organizations in the mechanical engineering sector (Bacho et al, 2019; Lukjanova, Sushchenko \& Zyma, 2019). This necessitates exploring the levels of development of the professional competencies of the employees, and revealing the possibilities for their further growth and enhancement. (Sushchenko \& Basyuk, 2019 ; Naama, 2001 ; Naama, 2011).

In this regard, examining the level of the vocational competencies of the workforce in profit-making mechanical engineering companies can help clarify the power of the relationship between competence development and improvement and the ultimate economic outcome.

The purpose of this article is to analyze the status and development of the professional competencies of the labor force in the mechanical engineering sector, and to evaluate their role in improving the economic situation in the business organizations in Bulgaria.

The article is structured into two main sections. The first involves an analysis of professional competencies, examining the links with and relation to the production and economic performance. The second section presents a model of professional competencies which are particularly important for achieving high economic result in the businesses in the Bulgarian mechanical engineering sector. 


\section{MATERIALS AND METHODS}

In order to assess the status of the professional competencies of the workforce, influencing and interacting with the production and economic results, the views of owners, managers and specialists in the human resources management /HRM/ in 68 varying in size, status and legal structure companies in the mechanical engineering sector were examined and analyzed. Most of them are located on the territory of Plovdiv, Haskovo, Pazardzhik and Stara Zagora regions.

By size, the surveyed business organizations are grouped into four groups, namely:

- 1 to 10 employees $-14.7 \%$

- 11 to 50 employees $-38.6 \%$

- 51 to 100 employees $-27.9 \%$

- Over 101 employees $-18.8 \%$

The selection of organizations in the field of mechanical engineering is based on the positive economic results achieved by them, or the realized profit for the last three years prior to the survey. The effect and interaction of the professional competencies affecting the size of profit in the organizations studied is examined using the Pearson correlation analysis. For the purposes of the above, the organizations are considered according to their legal form. The first type involves Sole Trader Organizations (ST). They are predominantly small in size and their production is mainly intended for the local markets. The second and third types are capital companies. Sole Owner Limited Liability Companies /Ltd./ and Limited Liability Companies /LLC/. In these businesses, the main factors for achieving.

The participants in the study has previously received a list of 20 major groups of professional competence as well as their concise definition and description. (Table 1). They were asked to rank them in a five-point scale, namely: 1 - not important, 2 - somewhat important, 3 - important 4 - very important, 5 - extremely important.

Table 1. Description of the main groups of professional competence

\begin{tabular}{|c|l|l|}
\hline № & Competence & \multicolumn{1}{c|}{ Description } \\
\hline 1 & Adaptability & $\begin{array}{l}\text { Ability to adapt to the corporate culture, flexibility, quick } \\
\text { orientation to the demands of the changing environment, } \\
\text { including the ability to work under pressure and tight } \\
\text { deadlines }\end{array}$ \\
\hline 2 & $\begin{array}{l}\text { Readiness and } \\
\text { willingness to learn }\end{array}$ & $\begin{array}{l}\text { Receptivity, curiosity, desire for self-improvement, seeking } \\
\text { and receiving feedback }\end{array}$ \\
\hline 3 & Loyalty & Ethical attitude, honesty, integrity \\
\hline 4 & Efficiency & Ability to cope with work tasks with good results \\
\hline 5 & Computer skills & Using word processors, spreadsheets, Internet applications \\
\hline
\end{tabular}




\begin{tabular}{|c|c|c|}
\hline 6 & Leadership skills & $\begin{array}{l}\text { Skills in planning, managing and motivating people, skills in } \\
\text { decision-making, negotiation, etc.. }\end{array}$ \\
\hline 7 & Mathematical skills & $\begin{array}{l}\text { Working with numbers, accuracy, methodical skills, } \\
\text { precision }\end{array}$ \\
\hline 8 & $\begin{array}{l}\text { Ability to work in a } \\
\text { team }\end{array}$ & $\begin{array}{l}\text { Cooperation, conflict resolution, good interpersonal } \\
\text { relations, sociability, ability to build relationships }\end{array}$ \\
\hline 9 & Motivation & Positive work attitude, enthusiasm \\
\hline 10 & Professional skills & $\begin{array}{l}\text { Specific skills and knowledge of the professional field, an } \\
\text { adequate idea of the work }\end{array}$ \\
\hline 11 & $\begin{array}{l}\text { Communication } \\
\text { skills }\end{array}$ & $\begin{array}{l}\text { Clear, convincing and literate expression in oral and written } \\
\text { form }\end{array}$ \\
\hline 12 & Critical attitude & Analytical skills, logic, impartiality, accuracy \\
\hline 13 & Office skills & $\begin{array}{l}\text { Finding and organizing information, documents, data; work } \\
\text { habits and use of office equipment }\end{array}$ \\
\hline 14 & $\begin{array}{l}\text { Entrepreneurial } \\
\text { skills }\end{array}$ & $\begin{array}{l}\text { Initiative, entrepreneurship, business knowledge and insight, } \\
\text { determination, ability to make decisions and take risks }\end{array}$ \\
\hline 15 & $\begin{array}{l}\text { Self-presentation } \\
\text { skills }\end{array}$ & $\begin{array}{l}\text { Skills for successful performance (including in a job } \\
\text { application and interview), confidence in one's own skills, } \\
\text { positivity, conviction, knowledge of business } \\
\text { communication }\end{array}$ \\
\hline 16 & Creativity & Creativity, initiative, ingenuity, lateral thinking \\
\hline 17 & Technical skills & $\begin{array}{l}\text { Specific skills to use specialized soft ware programs and } \\
\text { equipment }\end{array}$ \\
\hline 18 & attention & $\begin{array}{l}\text { Responsiveness, empathy, positive attitude, tact, tolerance, } \\
\text { patience, attentiveness }\end{array}$ \\
\hline 19 & $\begin{array}{l}\text { Self-management } \\
\text { skills }\end{array}$ & $\begin{array}{l}\text { Responsibility, independence, organization of time and work } \\
\text { tasks }\end{array}$ \\
\hline 20 & $\begin{array}{l}\text { Multilingual } \\
\text { abilities }\end{array}$ & $\begin{array}{l}\text { Use (written and spoken) of a foreign language, intercultural } \\
\text { experience and knowledge }\end{array}$ \\
\hline
\end{tabular}

The actual list has been prepared for the purposes of the study, in which the following were taken into account:

- Key competencies formulated by the European Commission ${ }^{1}$;

- Preliminary analysis of similar studies in Europe and around the world in recent years ${ }^{2}$;

- Overview of the most frequently mentioned skills and qualities that are required from applicants in job advertisements ${ }^{3}$,

- Consultations with employers, educational experts and counselors who helped summarizing the skills in 20 groups $^{4}, 5$.

\footnotetext{
1 Employers'perception of graduateemployability, FlashEurobarometer, 2010 //http://ec.europa.eu/public_opinion/ flash/fl_304_en.pdf

2 Graduate Employability: What do employers think and want? 2008 //http://ec.europa.eu/education/highereducation/doc/business/graduate_en.pdf);

3 Lisbon Council - "Europe 2020: Why Skills are Key for Europe's Future", http://www.lisboncouncil.net/ publication/publication/54-skillseuroprsfuture.html

${ }^{4}$ Ready to grow:business priorities for education and skills. Education and skills survey, http://www.cbi.org.uk /ndbs/content.nsf/802737AED3E3420580256706005390AE/C4393B860D00478E802576C6003B0679)

${ }^{5}$ The Definition And Selection Of Key Competencies, http://www.oecd.org/data oecd/47/61/35070367.pdf
} 
The second section presents a model of professional competencies of the workforce. It addresses those that are of particular importance for achieving high economic performance in the business organizations in the mechanical engineering sector. To build this model, the Path-coefficient analysis technique was applied. This method combines the capabilities of the correlation, regression and structural analysis. This makes it one of the most appropriate methods of studying relationships, as Path-analysis examines not only the direct but also the indirect links between the state of the professional competencies of the human resources and the economic performance of the organizations. In this way, those with the strongest impact are assessed, while the weak ones are eliminated.

The survey covers the period October 2018 - January 2019. The data and information are collected through direct contact and completion of specially developed questionnaires for the purposes of the analysis. Moreover, the interview method is used to clarify the information. The data processing and analysis uses the statistical package SPSS 13.0 and Microsoft Office (Word, Excel, Power Point).

\section{RESULTS AND DISCUSSION}

Research on the professional competencies of the workforce, influencing and interacting with the economic results in the business organizations in the mechanical engineering sector

The analysis of the data reveals that in the organizations of the mechanical engineering sector Professional skills $/ \mathrm{R}=0.839$ at $\alpha=0.01 /$ has the strongest influence on the final economic results. Its influence is particularly significant in Sole Owner Limited Liability Companies. They have a very high correlation coefficient of 0.879 , statistically proven at $\alpha=0.01$. The importance of the Professional skills is also proven at SL /R=0.755 at $\alpha=0.01 /$ and $\mathrm{LLC} / \mathrm{R}=0.806$ at $\alpha=0.01 /$. (Table 2.)

Table 2. Impact of the professional competencies on the economic situation of the business organizations in the mechanical engineering sector

\begin{tabular}{|l|l|l|l|l|}
\hline \multirow{2}{*}{\multicolumn{1}{|c|}{ Professional competence }} & \multicolumn{3}{c|}{ Correlation coefficients } \\
\cline { 2 - 5 } & \multicolumn{1}{|c|}{ Total } & \multicolumn{1}{c|}{ SL } & \multicolumn{1}{c|}{ Ltd. } & \multicolumn{1}{c|}{ LLC } \\
\hline Adaptability & $0,694^{* *}$ & $0,503^{* *}$ & $0,724^{* *}$ & $0,661^{* *}$ \\
\hline Readiness and willingness to learn & $0,787^{* *}$ & $0,683^{* *}$ & $0,821^{* *}$ & $0,736^{* *}$ \\
\hline Loyalty & 0,407 & 0,383 & 0,301 & 0,337 \\
\hline Efficiency & $0,628^{* *}$ & $0,643^{* *}$ & $0,479^{*}$ & $0,618^{* *}$ \\
\hline Computer skills & & & & \\
\hline Leadership skills & $0,446^{*}$ & 0,341 & $0,455^{*}$ & $0,436^{*}$ \\
\hline Mathematical skills & 0,264 & 0,299 & 0,238 & 0,254 \\
\hline Ability to work in a team & 0,197 & 0,126 & 0,257 & 0,123 \\
\hline Motivation & $0,728^{* *}$ & $0,488^{*}$ & $0,831^{* *}$ & $0,669^{* *}$ \\
\hline Professional skills & $0,584^{* *}$ & $0,593^{* *}$ & $0,631^{* *}$ & $0,477^{*}$ \\
\hline Communication skills & $0,839^{* *}$ & $0,755^{* *}$ & $0,879^{* *}$ & $0,806^{* *}$ \\
\hline Critical attitude & $0,514^{*}$ & 0,424 & $0,663^{* *}$ & $0,498^{*}$ \\
\hline
\end{tabular}




\begin{tabular}{|l|l|l|l|l|}
\hline Office skills & 0,336 & 0,418 & 0,347 & 0,223 \\
\hline Entrepreneurial skills & 0,247 & 0,211 & 0,278 & 0,286 \\
\hline Self-presentation skills & $0,511^{*}$ & $0,458^{*}$ & 0,416 & 0,379 \\
\hline Creativity & 0,374 & $0,479^{*}$ & 0,316 & 0,351 \\
\hline Technical skills & 0,228 & 0,184 & 0,263 & 0,191 \\
\hline Client attention skills & 0,423 & 0,407 & $0,445^{*}$ & 0,331 \\
\hline Self-management skills & $0,672^{* *}$ & $0,537^{*}$ & $0,716^{* *}$ & $0,658^{* *}$ \\
\hline Multilingual abilities & $0,694^{* *}$ & $0,503^{* *}$ & $0,724^{* *}$ & $0,661^{* *}$ \\
\hline Respondents, \% & 100 & 33,6 & 36,8 & 29,6 \\
\hline
\end{tabular}

Source: Own calculations

*Correlation is significant at the 0.05 level; **Correlation is significant at the 0.01 level

Of particular importance for the positive economic outcome is the Readiness and willingness to learn. The data show that this competence most significantly influences the capital companies, with correlation coefficients of 0.821 and 0.736 respectively at $\alpha=0.01$. Similar results are also observed with SL holdings.

Professional competencies, such as Ability to work in a team $/ \mathrm{R}=0.728 /$; Adaptability $/ \mathrm{R}=0.694 /$; Selfmanagement skills $/ \mathrm{R}=0.663 /$; Efficiency $/ \mathrm{R}=0.611$ / and Motivation $/ \mathrm{R}=0,576 /$ also have a strong impact on the final economic performance of the organizations in the engineering sector. The high correlation coefficients, statistically proven at $\alpha=0.01$, reveal their role in achieving higher production and economic results in the business organizations in focus. A strong correlation with profit is also observed in Computer Skills / $\mathrm{R}=0,449$ at $\alpha=0,05 /$ and Communication skills $/ \mathrm{R}=0,524$ at $\alpha=0,05 /$, Self-presentation skills $/ \mathrm{R}=0,496$ at $\alpha=0,05 /$ as well as Multilingual abilities $/ \mathrm{R}=0,523$ at $\alpha=0,05 /$.

With Limited Liability Companies, Adaptability $/ \mathrm{R}=0.674 /$, Ability to work in a team $/ \mathrm{R}=0.667 /$, Efficiency $/ \mathrm{R}=0.623 /$, Self-management $/ \mathrm{R}=0.672 /$ and Multilingual abilities $/ \mathrm{R}=0,597 /$ are particularly important for enhancing the production and economic performance. Their interaction with the profit made shows high correlation coefficients, statistically proven at $\alpha=0.01$. Computer skills, Motivation and Communication skills also play an important role in rising the economic performance of these organizations.

The Sole Owner Limited Liability Companies demonstrate similar results. A strong correlation is evidenced between the professional competencies Adaptability $/ \mathrm{R}=0.724$ at $\alpha=0.01 /$, Ability to work in a team $/ \mathrm{R}=0.831$ at $\alpha=0.01 /$, Motivation $/ \mathrm{R}=0.631$ at $\alpha=0.01 /$, Communication skills $/ \mathrm{R}=0.663$ at $\alpha=0.01 /$, Self-management skills $/ \mathrm{R}=0.716$ at $\alpha=0.01 /$ and Multilingual abilities $/ \mathrm{R}=0.668$ at $\alpha=0.01 /$ and the high production and economic performance of the organizations in mechanical engineering.

In SL companies, the enhanced economic performance is highly dependent on Efficiency / $\mathrm{R}=0.643 /$, Adaptability $/ \mathrm{R}=0.503 /$ and Motivation $/ \mathrm{R}=0.593 /$.

The impact of these professional competency groups is statistically proven at $\alpha=0.01$. With Ability to work in a team $/ R=0.488 /$, Self-presentation skills $/ R=0.458 /$, Self-management skills $/ R=0.537 /$, Creative skills $/ \mathrm{R}=0.479 /$, and Multilingual abilities $/ \mathrm{R}=0.437 /$, there is also a strong positive interdependence with good production and economic results. This is confirmed at $\alpha=0.05$. 
From the data displayed, it can be concluded that a number of similar results are observed when examining the interrelations and links of the professional competencies with the production and economic performance of the three types of companies according to their legal and organizational form.

Adaptability, Professional skills, Readiness and willingness to learn, Self-management and Motivation are competencies which are of particular importance for profit making in both, capital companies and SL organizations.

There is a slight difference in the power of influence in terms of Ability to work in a team, Communication skills and Multilingual abilities. They are rated as particularly important in the organizations of the capital companies, while their influence at the SL is weaker.

In SL organizations, the relationship between Self-presentation skills and Creative Skills with the declared profit is statistically proven at $\alpha=0.05$. At these companies, these professional competencies are not particularly significant.

The Client attention skills is a substantial professional competency for the Sole Owner Limited Liability Companies. In the organizations of SL and LLC the Efficiency of the workforce is of particular importance for increasing the economic results.

At the analysis of the rest of the professional competencies, we did not establish a statistically proven correlation between them and the profit made during the research period. Medium and low levels of correlation coefficients are reported, while the least important for achieving positive economic results in the business organizations in the mechanical engineering sector are Technical skills and Mathematical skills.

The analysis reported shows the relationship and the impact of the presented professional competencies on the economic situation of the businesses in the mechanical engineering sector. On the basis of this, a combination of competencies with the greatest impact on the economic situation of the business organizations can be proposed.

\section{Modeling of the professional competencies which directly or indirectly affect the economic situation of the business organizations in the mechanical engineering sector}

The Path-analysis method was applied to study the impact of both, the direct and indirect links of the professional competencies on the economic status of the business organizations in the mechanical engineering sector. This method assesses only those competencies which exercise the strongest impact on the economic performance, while the weak ones are eliminated. The results obtained from the performed Path analysis are shown in Table 3.

The information in the table reveals that some of the professional competencies have a positive direct and indirect impact on the economic status of the organizations studied. These competencies are rated as very positive. 
Table 3. Direct and indirect effect of the professional competencies affecting the economic condition of the business organizations in the mechanical engineering sector

\begin{tabular}{|l|c|c|}
\hline \multirow{2}{*}{\multicolumn{1}{|c|}{ Professional competence }} & \multicolumn{2}{c|}{ Path-coefficients } \\
\cline { 2 - 3 } & Direct effect & Indirect effect \\
\hline Professional skills & 0,549 & 0,290 \\
\hline Readiness and willingness to learn & 0,916 & $-0,129$ \\
\hline Creativity & $-0,366$ & 0,740 \\
\hline Efficiency & 0,464 & 0,164 \\
\hline Self-presentation skills & 0,725 & $-0,214$ \\
\hline Adaptability & 0,521 & 0,173 \\
\hline Multilingual abilities & 0,869 & $-0,272$ \\
\hline Ability to work in a team & 0,491 & 0,237 \\
\hline Communication skills & 0,807 & $-0,293$ \\
\hline Motivation & 0,477 & 0,107 \\
\hline Critical attitude & $-0,367$ & 0,664 \\
\hline Self-management skills & 0,476 & 0,196 \\
\hline Entrepreneurial skills & $-0,208$ & 0,455 \\
\hline Loyalty & 0,644 & $-0,237$ \\
\hline Own calculations & & \\
\hline
\end{tabular}

These include Professional skills, Efficiency, Adaptability and Ability to work in a team. The professional competencies Self-management and Motivation skills are also very positive.

Self-presentation skills, Readiness and willingness to learn, Communication skills, Multilingual abilities and Loyalty have a direct positive effect on the economic status of the organizations in the engineering sector. However, the indirect impact of this group of professional competencies on the overall economic performance is negative.

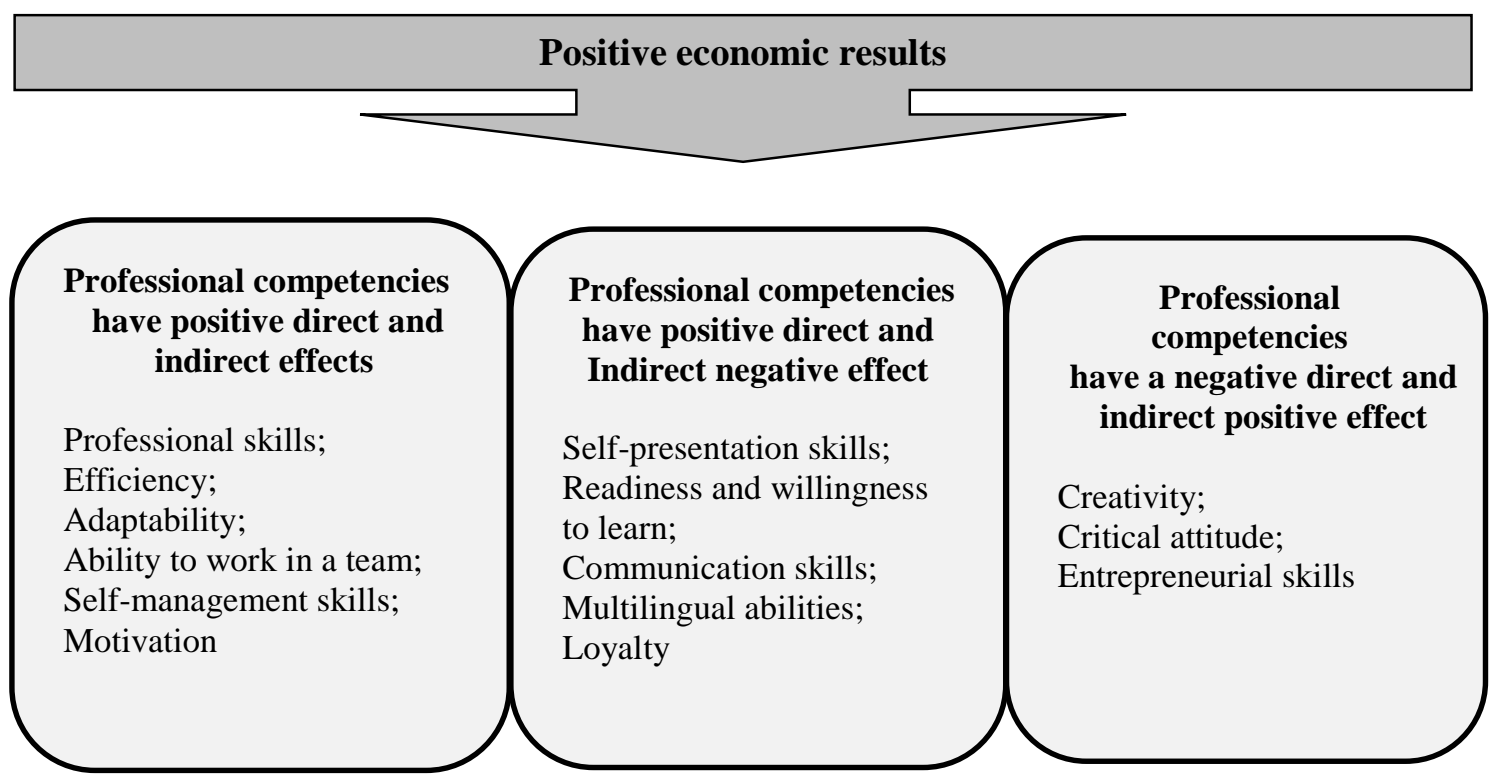

Figure 1. Model of the professional competencies having a direct and indirect effect on the economic situation of the business organizations in the mechanical engineering sector 
The third group of professional competencies, to which the Creative skills, Critical attitude and Entrepreneurial skills apply, have a direct negative impact on the economic situation of the businesses in the mechanical engineering sector. On the other hand, their indirect influence is very positive. The coefficient of the indirect effect exceeds that of the direct and the ultimate influence of these competencies is also positive.

The modeling of professional competencies, which have a positive impact on the economic situation, helps to establish a complete system for the selection, training and professional development of the managers and employees in the business organizations in the mechanical engineering sector. (Figure1.)

The implementation of the system shows the effect of the practical application of the professional competencies, as well as their action and interaction for improving the economic status of the businesses. Their sophistication has helped to improve communication and relationships between all employees of the business organizations. The motivation of the human resources is increased to reach better performance of the work tasks. The achieved result of the implemented activities is the introduction of a legally established and effectively functioning system for the selection, training and professional development of the workforce, contributing to the improvement of the economic status of the companies in the field of mechanical engineering.

\section{CONCLUSIONS}

Building a set of professional competencies requires focused work to improve certain knowledge, skills and abilities. They have a direct or indirect impact on the results of the production and economic activity in the business organizations in the mechanical engineering sector. It is therefore of the utmost importance to examine the state of professional competencies by opening up opportunities for their effective use and management.

The analysis reported hereby shows the relationship and the impact of the presented professional competencies on the economic status of the companies in focus. Based on this research, a combination of competencies which have the greatest impact on the economic performance in the organizations can be proposed.

The modelling of professional competencies, which have a positive impact on the economic situation, contributes to the establishment of a complete system for the selection, training and professional development of the workforce in the business organizations in the mechanical engineering sector.

\section{Conflict of interests}

The authors declare no conflict of interest. 


\section{References}

Bacho, R., Pukala, R., Hlibko, S., Vnukova, N., Pola, P. (2019). Information Management: the Key Driver of the Economic System's Development. Marketing and Management of Innovations, 3, $297-307$. http://doi.org/10.21272/mmi.2019.3-23

Employers' perception of graduate employ ability, Flash Eurobarometer, (2010). http://ec.europa.eu/pub lic_opinion/flash/fl_304_en.pdf)

Graduate Employability: What do employers think and want? (2008) http://ec.europa.eu/education/highereducation/doc/business/graduate_en.pdf);

Koval V., Duginets G., Plekhanova O., Antonov A., Petrova M. (2019) On the supranational and national level of global value chain management. Entrepreneurship and Sustainability Issues, Vol 6 Number 4 (June), http://jssidoi.org/jesi/

Levashova, L. (2011). Rozwój kariery zawodowej pracowników w aspekcie innowacji, w: Innowacje przedsiębiorstw a satysfakcja klientów w teorii i w praktyce, pod redakcją naukowa Świerszcz K. i Śliwa J. Warszawa: Wydawnictwo Społeczna Wyższa Szkoła Przedsiębiorczosci i Zarządzania w Łodzi.

Lisbon Council - "Europe 2020: Why Skills are Key for Europe's Future", http://www.lisboncouncil,net/publication/publication/54-skillseuroprsfuture.html

Lukjanova, J., Sushchenko, O., Zyma, O. (2019). Educated and Competent Staff as Important Factor of Innovation Development of Machine-Building and Metalworking Industry in Latvia. X International Scientific and Practical Conference "Innovations in Mechanical Engineering" (ISPCIME-2019). MATEC Web of Conferences, vol.297 (06006), 2019, DOI: https://doi.org/10.1051/matecconf/201929706006

Mikhailov, V., Karasev, V., Mikhailov, G. (2018). The Study of the Main Indicators of the Local Environmental and Economic System "Industrial Enterprise-Environment". E3S Web Conf. Volume 41, 2018. III ${ }^{\text {rd }}$ International Innovative Mining Symposium, https://doi.org/10.1051/e3sconf/20184102015

Mussapirov, K., Djalkibaev, J., Kurenkeyeva, G., Kadirbergenova, A., Petrova, M., Zhakypbek, L. 2019. Business scaling through outsourcing and networking: selected case studieS, Entrepreneurship and Sustainability Issues, 7(2), 14801495. http://doi.org/10.9770/jesi.2019.7.2(48)

Naama, K. (2018). Development of the Arab Economy after the “Arab Spring”. European Journal of Science and Research. ISSN 2544-4573. Issue 2/2018, pp 92-100.

Naama, K. (2010). Evaluation of the privatization program in ARAB REPUBLIC of EGYPT. Economic Studies. Vol. 19 Issue 1, p118-149. 32p.

Naama, K. (2001)."International Movement of Foreign Direct Investments," Economic Thought journal, Bulgarian Academy of Sciences - Economic Research Institute, issue 5, pages 81-92.

Naama, K. (2011). Problems and Solutions for Establishing the Private Sector in Developing Countries. Economic Archive. D. A.Tsenov Academy of Economics- Svishtov. ISSN: 0323-9004, eISSN: 2367-9301, Issue 1, pp. 28-41

Nikolova-Alexieva V., Teneva A., Yordanova P. (2018), Survey of How Process Modeling Works in the Bulgarian Organizations, International Conference on High Technology for Sustainable Development (HiTech) doi.org/10.1109/ hitech.2018.8566320

Pukala R. Petrova, M. (2019). Application of the AHP method to select an optimal source of financing innovation in the mining sector. E3S Web of Conferences Volume 105. IV th IIMS, EDP Sciences, DOI: https://doi.org/ $\underline{10.1051 / \mathrm{e} 3 \text { sconf/201910504034 }}$

Ready to grow: business priorities for education and skills. Education and skills survey, 2010, http://www.cbi.org.uk/ndbs/content.nsf/802737AED3E3420580256706005390AE/C4393B860D00478E802576C 6003B0679)

Sushchenko, O. (2016). Creation of innovation clusters as a line of enterprise competitiveness improvement in the field of foreign economic activity, Actual Problems of Economics, 177(3), 191-198

Sushchenko, O., Basyuk, D. (2019). Organization of Personnel Training in the HR-Management System at MachineBuilding Enterprises. X International Scientific and Practical Conference "Innovations in Mechanical Engineering" (ISPCIME-2019). MATEC Web of Conferences, EDP Sciences, vol.297 (07006), 2019, DOI: https://doi.org/10.1051/matecconf/201929707006

The Definition And Selection Of Key Competencies, http://www.oecd.org/data oecd/47/61/35070367.pdf 
Uteubayev T., Petrova M., Lyubenova I. (2018), Training of qualified specialists in the process of their education at the university: the role of the public-private partnership. CBU international conference proceedings 2018: Innovations in science and education Book Series: CBU International Conference Proceedings Pages, pp. 491-495.

Vazov R. (2019). Inovative Approaches to Insurance Company Cash Flow Management (contemporary theoretical aspects). Sofia: VUZF Publishing House "St. Grigorii Bogoslov", ISBN: 978-954-8590-54-9, 136 p.

Zagorodnya, A., Dichek, N., Chobitko, N., Voznyk, M., Honchar, L., Petrova, M. (2020). Professional training of the economic sector specialists at higher education institutions of the Republic of Poland and Ukraine: criteria of comparison. International Journal of Higher Education, Vol. 9, No. 3, June 2020, pp.139-144, https://doi.org/10.5430/ijhe.v9n3p139

\section{About the authors:}

Milena TEPAVISHAROVA, Professor of Business Enterprise and Innovation, Ph.D, Faculty of Economics and Management, Higher School of Security and Economics, Bulgaria.

Research interests: entrepreneurship and regional development; innovation and small firms; small firm internationalization; sustainability.

ORCID ID: https://orcid.org/0000-0003-3759-5426

Ludmila ALEKSEJEVA, Assoc. professor, PhD, Head of Department of Economics and Sociology, Faculty of Social Science, Daugavpils university, Daugavpils, Latvia.

Research interests: entrepreneurship and regional development; innovation and small firms; sustainable development in rural territories; challenges in smart growth; regional development in small municipalities

ORCID ID: https://orcid.org/0000-0002-1965-0818 